chenschr 1979;104:381-4.

5. Takahashi K, et al. Association of Daneparticles with $\mathrm{e}$ antigen in the serum of asymptomatic carriers of hepatitis B surface antigen. J Immunol 1976;117:102-5.

6. Thraenhart $O$, et al. Morphologische Veränderungen und Desintegration von
Dane-Partikeln nach Gigasept-Behandlung. Ein erster Versuchsansatz zur Beurteilung der Hepatitis-Virus-B-Viruzide chemischer Desinfektionsmittel. Zentralbl Bakteriol Mikrobiol Hyg [B] 1977; $164: 1$.

\title{
The Application of Laser to Otolaryngology
}

\author{
WANG Qi (王 奇) \\ Department of Otolaryngology, Tongji Hospital, \\ Tongii Medical University, Wuhan
}

The author employed lasers with different power selectively for treating various lesions. These laser-therapies include treatment of chronic hypertrophic rhinitis by using 40 Watt $\mathrm{CO}_{2}$ laser and the treatment of nevi and warts in the ear and nose or on the head and neck, and localized telangiectasis and benign tumours by employing 10 Watt $\mathrm{CO}_{2}$ laser.

Some tumours could be resected and vaporized by laser with full exposure of the lesion in the case of laryngeal carcinoma, some skin and intracranial tumours, and maxillar sinus cancer which is treated by cryotherapy and laser-therapy in combination. Some treated cases have been followed up for $3-5$ years without signs of recurrence.

Superficial benign and malignant tumours over large areas such as angioma and melanoma can be treated with high energy light beam (argon and $\mathrm{CO}_{2}$ laser) by scanning.

\section{A Study of ABR Test about Inner Ear Membrane Lymphatic Hydrops in Guinea Pigs}

\author{
WANG Qi (王 奇)*, K.J.Lee, Leslie May
}

This paper presents an experiment of auditory brainstem evcked potential reaction (ABR) test on inner ear membrane lymphatic hydrcps in guinea pigs.

40 guinea pigs underwent endolymphatic sac obliteration operation as described by Kimura. Postoperatively, 23 guinea pigs could fulfill the conditions needed, i.e., the animals survived from the procedure without distinct nystagmus but with obviously abnormal ABR wave.

Typical postoperative ABR wave showed protracted latency of $I-I$ and $I-V$ with a normal latency of $\mathbb{I}-\mathbf{I}$, and wave I was obvicusly prolonged with its amplitude reduced.

Convexity of the Reissner's membrane and slight hydrops of the saccule and dilated utricles were found in the cochlea scala media.

It is interesting that in one case pathological fibrosis was found with fibrous connective tissue filling the cochlea but without apparent inflammation. At the operated site a lot of scar and newly formed bone tissue developed but the vestibule showed collapsed saccule and atrophied epithelial cells.

* Department of Otolaryngology, Tongji Hospital, Tongji Medical University, Wuhan 